\title{
ПРОФЕСІЙНЕ ВИГОРАННЯ СОЦІАЛЬНИХ ПРАЦІВНИКІВ
}

\author{
Рідкодубська Г. А. \\ доктор педагогічних наук, дочент, \\ професор кафедри соичіальної роботи і соиіальної педагогіки \\ Хмельницький начіональний університет \\ вул. Інститутська, 11, Хмельницький, Україна \\ orcid.org/0000-0003-0561-6835 \\ Anutabanditka1@ukr.net
}

\author{
Ключові слова: \\ професійне вигорання, \\ сочзіальні працівники, \\ профілактика «професійного \\ вигорання», методичні \\ рекомендації соціальним \\ працівникам, діагностика \\ «професійного вигорання».
}

У статті розглядаються основні підходи до поняття «професійне вигоряння» й аналізуютьсядані емпіричногодослідження, які проводилися в м. Хмельницькому із соціальними працівниками 3 метою виявлення в них симптомів «професійного вигорання». Аналіз наукових джерел доводить, що синдрому «професійного вигорання» присвячено велику кількість досліджень як вітчизняних, так й іноземних науковців. У працях аналізуються структурні елементи походження та прояви синдрому, основні його компоненти. Однак нині актуальною та невизначеною залишається відсутність системи роботи 3 професійним вигоранням соціальних працівників. Лише 32001 р. синдром «професійного вигоряння» ВОO3 визнала як проблему. Проаналізовано основні симптоми «професійного вигорання» та систематизовано причини появи цього негативного явища. Аналізуються результати експериментальних досліджень, які проводилися в м. Хмельницькому із соціальними працівниками. Емпіричне дослідження проводилося 3 використанням таких методик: «Оцінювання професійного стресу» (опитувальник К. Вайсмана), «Професійне вигоряння» (опитувальник Н. Водопьянова) і методики діагностики емоційного вигоряння (автор В. Бойко). Результати доводять актуальність і доречність виконаної роботи. На першому місці в респондентів виявлено емоційне вигорання, редукція знаходиться на другому місці в проявах «професійного вигорання» соціальних працівників, на третьому місці - деперсоналізація. Автор пропонує методичні рекомендації щодо зниження ризику появи «професійного вигорання» та мінімізації симптомів цієї проблеми. Пропонуються такі форми роботи для подолання «професійного вигорання» соціальних працівників: включення елементів тим-білдингу в професійну діяльність соціальних працівників, проведення психологічних майстер-класів із розвитку професійної мобільності, індивідуальна, групова робота 3 психологом, коучем із розвитку стресостійкості, включення різного роду завдань з організації життєвого простору, тайм-менеджменту та швидкого перелаштування з одного виду діяльності на інший, постійне підвищення рівня професійної кваліфікації, самоосвіта. 


\title{
PROFESSIONAL BURNING OUT OF SOCIAL WORKERS
}

\author{
Ridkodubska H. A. \\ Doctor of Pedagogical Sciences, Associate Professor, \\ Professor at the Department of Social Work and Social Pedagogy \\ Khmelnitsky National University \\ Instytuts'ka str., 11, Khmelnitsky, Ukraine \\ orcid.org/0000-0003-0561-6835 \\ Anutabanditka1@ukr.net
}

\section{Key words:}

professional burnout, social workers, prevention of "professional burnout", methodical recommendations to social workers, diagnosis of "professional burnout".
The article considers the main approaches to the concept of "professional burnout" and analyzes the data of an empirical study conducted in Khmelnytsky with social workers in order to identify symptoms of "professional burnout". Analysis of scientific works shows that the syndrome of "professional burnout" is devoted to a large number of studies as domestic and foreign scientists. The works analyze both the structural elements of the origin and appearance of the syndrome, and its main components. However, the current lack of a system for dealing with burnout of social workers remains relevant and uncertain. Only since 2001 has the WHO recognized burnout as a problem. The main symptoms of "professional burnout" are analyzed and the causes of this negative phenomenon are systematized. The article analyzes the results of empirical research conducted in Khmelnytsky with social workers.

Empirical research was conducted using the following methods: "Assessment of occupational stress" (questionnaire byK. Weissman), "Professional burnout" (questionnaire by N. Vodopyanov) and Methods of diagnosis of emotional burnout (author V. Boyko). The results prove the relevance and relevance of the work performed.

In the first place, the respondents found emotional burnout of social workers in the city of Khmelnytsky, the reduction is in the second place in the manifestations of "professional burnout" of social workers, in the third place depersonalization. Within the article, the author offers guidelines for reducing the risk of "burnout" and minimizing the symptoms of this problem.

The following forms of work are proposed to overcome the "professional burnout" of social workers: the inclusion of elements of team building, psychological workshops on the development of professional mobility, the inclusion of various tasks for living space, time management and rapid relocation from one activity to another, constant improvement of the level of professional qualification, self-education, all these are the best ways to reduce the manifestations of «professional burnout».
Постановка проблеми. Проблема професійного вигоряння актуальна для всіх професій типу людина-людина. I це зрозуміло, адже надання професійної допомоги завжди емоційно забарвлене, а результат вимірюється лише якісними показниками, що, як правило, не враховують психоемоційної шкали взаємодії. Особливість професійної діяльності соціального працівника визначається великою кількістю міжособистісних контактів, які, у свою чергу, формують психологічний стан працівника соціальної сфери, можуть викликати емоційне напруження та появу стресових станів. Усім нам відомо, що емоції, навіть позитивні, виснажують нервову систему людини. Як результат довгострокового перебування в стресовій ситуації, поява синдрому професійного вигоряння. У 1974 році термін «staff burn-out» (вигорання працівників) увів американський психіатр Герберт Фрейденберг [1, с. 160].

У 1976 році американська дослідниця Христина Маслач до наукового обігу ввела поняття «емоційне вигорання». Замість терміна «staff burn-out», науковець запропонувала використовувати «вигорання» (припинення горіння). У дослідженнях $\mathrm{X.} \mathrm{Маслач} \mathrm{пише} \mathrm{про} \mathrm{те,} \mathrm{що} \mathrm{«емоційне} \mathrm{вигорання,}$ 
яке $є$ причиною професійного вигорання, - це розплата за співчуття» [2, с. 420].

Нині існує багато теорій походження професійного вигоряння. Найбільш популярною залишається трикомпонентна теорія К. Маслач і С. Джексон, яка характеризує послідовну появу трьох груп симптомів: емоційне виснаження, деперсоналізацію й редукцію персональних досягнень [6, с. 13].

Ми поділяємо наукову позицію Н. Перхайла, який уважає, що «синдром професійного вигорання фахівців соціальної сфери є тим деструктивним фактором, що не лише знижує продуктивність діяльності працівників, свідчить про професійний регрес, незадоволеність самореалізацією, руйнує їхнє фізичне та психологічне здоров'я, а і є небезпекою для клієнтів, які звертаються до соціальних служб» [9, с. 208].

Аналіз наукових джерел доводить, що синдрому «професійного вигорання» присвячено велику кількість досліджень як вітчизняних, так й іноземних науковців. У працях аналізуються як структурні елементи походження й появи синдрому, так й основні його компоненти (В. Бойко, Н. Водоп'янова, Л. Карамушка, Т. Ронгинська, X. Маслач, Г. Фрейденберг та інші). Однак сьогодні актуальною та невизначеною залишається відсутність системи профілактики професійного вигоряння соціальних працівників.

Метою статті $\epsilon$ аналіз наявної проблеми синдрому професійного вигоряння, опис і характеристика профілактики професійного вигоряння соціальних працівників.

Виклад основного матеріалу дослідження. Професійна діяльність соціального працівника - допомогти клієнту шляхом підтримки, реабілітації чи ресоціалізації. Як ми бачимо, ключовим моментом професійної діяльності з клієнтом
$€$ взаємодія. Наявність якісної реакції соціального працівника на стресові події й визначає можливості потрапляння до категорії осіб із синдромом професійного вигоряння.

Синдром «професійного вигоряння» (burnout syndrome) ВОО3 визнала у 2001 році як проблему. У Міжнародній класифікації хвороб 10-го перегляду «синдром вигорання» виділено в окремий діагностичний таксон - Z73 Problems related to life-management difficulty (проблеми, пов'язані $з$ труднощами управління своїм життям), шифрується Z73.0 - Burn-out (вигорання) [8, с. 451.

Серед основних симптомів виокремлюють (узагальнено на основі аналізу праць $[1 ; 3 ; 4 ; 8]$ ) такі (табл. 1).

Велика кількість досліджень присвячена розумінню причин, що сприяють «вигоранню», i його наслідкам для людей та їхнього здоров'я. Ми погоджуємося 3 твердженнями науковців, що «стрес і «вигорання» $€$ важливими факторами появи фізичних і психосоматичних захворювань [3, с. 255]. Багато вчених (В. Бойко, Х. Маслач, Г. Фрейденберг) у дослідженнях доводять, що одним із найвагоміших факторів професійного вигоряння можна вважати емпатію $[1 ; 2 ; 4]$. Саме вона $є$ критерієм професійної орієнтації на професію «соціальний працівник», завдяки їй кожен клієнт може бути зорієнтованим на розуміння, душевне тепло й усвідомлення значущості власних переживань у професійній взаємодії з працівником соціальної сфери. Російський психолог В. Бойко виокремлює емоційне вигорання як вироблений особистістю механізм психологічного захисту у вигляді повної або часткової відсутності емоційного реагування у відповідь на психотравмувальний вплив [2, с. 59].

Ми проводили емпіричне дослідження рівня розвитку професійного вигоряння соціальних

Таблиця 1

\begin{tabular}{|c|c|c|c|c|}
\hline фізичні & емоційні & поведінкові & інтелектуальні & соціальні \\
\hline $\begin{array}{l}\text { втома, втомлюваність, } \\
\text { виснаження; безсон- } \\
\text { ня, запаморочення, } \\
\text { розлади травлення; } \\
\text { біль у серці; нудота, } \\
\text { тремтіння; артеріальна } \\
\text { гіпертензія; утруднене } \\
\text { дихання; коливання } \\
\text { ваги; скарги на погане } \\
\text { самопочуття загалом } \\
\text { тощо }\end{array}$ & $\begin{array}{l}\text { нестача емоцій, неемо- } \\
\text { ційність; песимізм, ци- } \\
\text { нізм, черствість у робо- } \\
\text { ті й особистому житті; } \\
\text { байдужість; фрустрація, } \\
\text { відчуття безнадійності; } \\
\text { агресивність, тривога, } \\
\text { нездатність зосереди- } \\
\text { тися; депресія, почуття } \\
\text { провини; втрата ідеалів, } \\
\text { надій чи професійних } \\
\text { перспектив; збільшення } \\
\text { деперсоналізації своєї } \\
\text { чи інших (люди почи- } \\
\text { нають сприйматися без- } \\
\text { ликими); переважання } \\
\text { почуття самотності }\end{array}$ & $\begin{array}{l}\text { постійне бажання } \\
\text { зробити перерву, } \\
\text { відпочити; запіз- } \\
\text { нення; байдужість } \\
\text { до їжі; відсутність } \\
\text { фізичних наван- } \\
\text { тажень; пошук } \\
\text { виправдання в } \\
\text { палінні, уживанні } \\
\text { кави, алкоголю, } \\
\text { ліків, інших психо- } \\
\text { активних речовин } \\
\text { тощо }\end{array}$ & $\begin{array}{l}\text { зниження інтересу } \\
\text { до нових теорій, } \\
\text { ідей, альтерна- } \\
\text { тивних підходів у } \\
\text { роботі; байдужість } \\
\text { до новинок, ново- } \\
\text { введень; відмова } \\
\text { від участі в розви- } \\
\text { ваючих експери- } \\
\text { ментах; формальне } \\
\text { виконання роботи } \\
\text { тощо }\end{array}$ & $\begin{array}{l}\text { низька соціаль- } \\
\text { на активність, } \\
\text { зниження (відсут- } \\
\text { ність) інтересу до } \\
\text { колишніх захо- } \\
\text { плень, хобі, сфери } \\
\text { дозвілля; обме- } \\
\text { ження соціальних } \\
\text { контактів тільки } \\
\text { вимушеними; } \\
\text { відчуття ізоля- } \\
\text { ції, недостатньої } \\
\text { підтримки з боку } \\
\text { сім’ї, друзів, ко- } \\
\text { лег; нерозуміння } \\
\text { оточуючими тощо }\end{array}$ \\
\hline
\end{tabular}


працівників м. Хмельницького, у дослідженні брали участь 20 соціальних працівників, $100 \%$ iз них мали вищу освіту, 10 (а це 50\%) - працювали від 2 до 5 років і $10(50 \%)$ - працювали від 5 до 10 років. Серед респондентів були лише жінки, тому розподілу за ознакою статі не було.

Під час експериментальної роботи ми використовували такі методики:

«Оцінювання професійного стресу» (опитувальник К. Вайсмана) [5];

«Професійне вигоряння» (опитувальник Н. Водопьянова) [4];

методику діагностики емоційного вигоряння В. Бойка [10].

Проаналізувавши отримані дані, ми зробили узагальнену таблицю, дані якої внесли до діаграми (рис. 1).

Виходячи 3 отриманих даних за результатами дослідження рівня професійного вигорання, робимо висновок, що проблема професійного вигорання працівників соціальної сфери $є$ досить актуальною, оскільки загалом у $35 \%$ досліджуваних виявлено ті чи інші симптоми «вигорання» у сформованій стадії. У 40\% соціальних працівників, які брали участь у дослідженні, «професійне вигорання» знаходиться на етапі формування, тому за відсутності коректної профілактичної та корекційної роботи існує небезпека появи симптомів «вигорання».

Як видно 3 діаграми, найвищі показники рівня розвитку професійного вигоряння в соціальних працівників м. Хмельницького виявлено у сфері емоційного виснаження (45\% високого рівня). Ці показники пояснюють той факт, що серед соціальних працівників - більшість жінок, які сприймають світ через призму емоцій і симтомно переживають вигорання, що «проявляється у відчутті постійної втоми, нервового збудження, зростанні тривожності, психосоматичних реакціях тощо» $[7$, с. 70$]$. Редукція, високий рівень якої виявлено в $35 \%$ опитаних, характеризується особистим відчуженням, знеціненням, «це хворобливе та нав'язливе усвідомлення фахової некомпетентності в професійній сфері, усвідомлення відсутності результативності, тенденція до негативного оцінювання себе, своїх професійних досягнень та успіхів, обмеження можливих шляхів професійного зростання» [8, с. 449].

Високий рівень деперсоналізації виявлено в $30 \%$ респондентів. Деперсоналізація визначається знеособлюванням взаємин із людьми, проявляється як деформація стосунків з іншими, цинічне ставлення до праці. Отже, аналіз даних, отриманих у ході експериментального дослідження, ще раз підтвердив актуальність і доцільність вирішення проблеми «професійного вигорання» соціальних працівників.

Кожен із виокремлених компонентів «професійного вигорання» $€$ важливою ознакою функціональних обов'язків соціальних працівників, саме тому необхідно розробити систему роботи із симптомами «професійного вигорання».

Ми поділяємо думку О. Керик, яка, визначаючи причини виникнення синдрому «професійне вигорання», виокремлює сукупність внутрішніх і зовнішніх чинників, до яких належать:

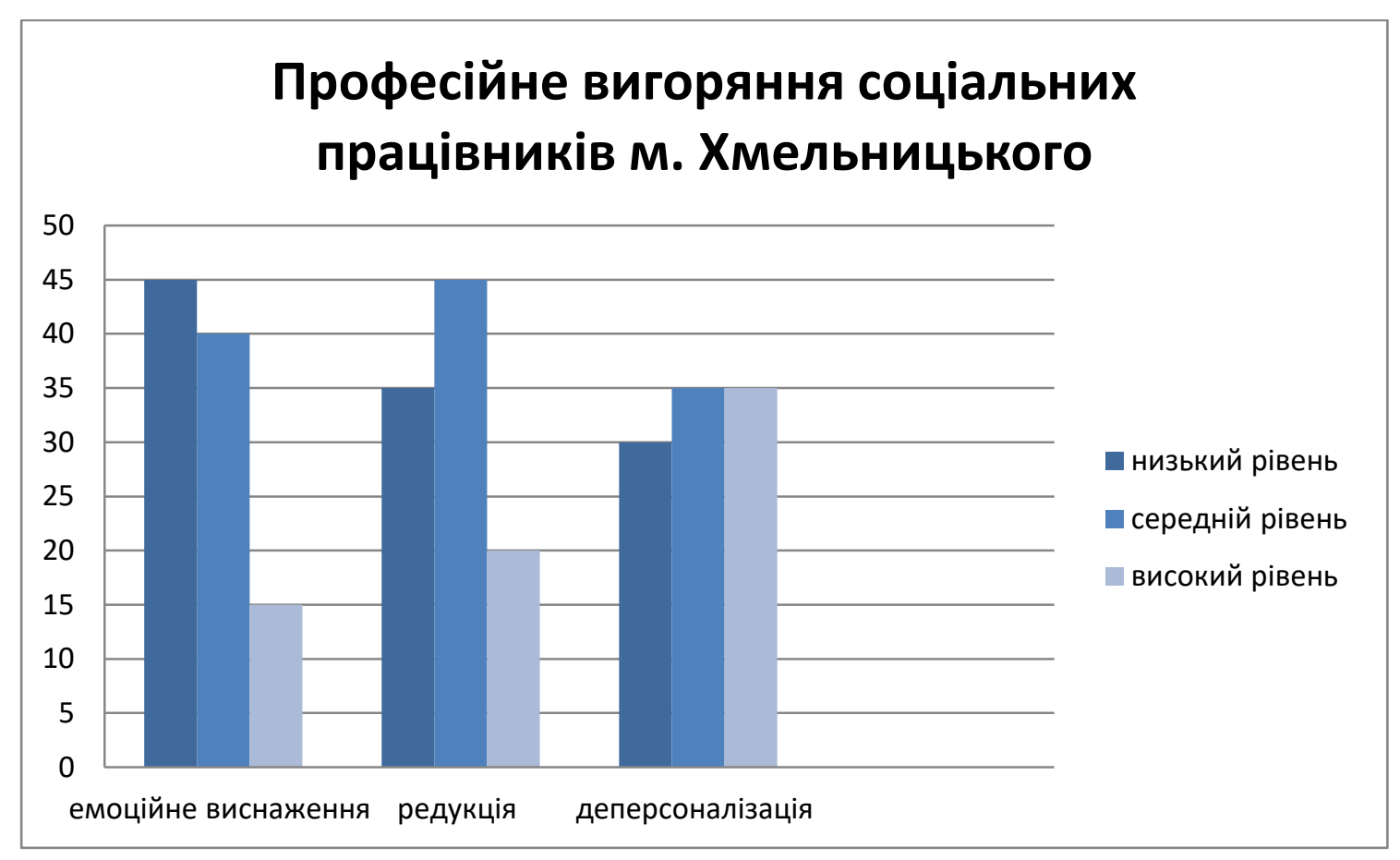

Рис. 1. 
- «схильність до емоційної ригідності - синдром частіше виникає в емоційно стриманих людей, у яких підвищена вразливість і чутливість блокують механізм психологічного захисту, а в людей більш імпульсивних формування зазначеного синдрому відбувається повільніше;

- слабка мотивація емоційної віддачі в професійній діяльності;

- хронічно напружена психоемоційна діяльність;

- дестабілізуюча організація діяльності (постійне присвячення себе роботі, коли вона замінює нормальне соціальне життя особистості);

- підвищена відповідальність під час виконання професійних обов'язків та ілюзія надважливості виконуваної роботи, яка є опорою самооцінки (якщо результат роботи не відповідає очікуванням, поступово втрачається ії значущість і цінність, що призводить до вигорання);

- ставлення до роботи як до важкої необхідності, що не приносить емоційного та професійного задоволення;

- рольові конфлікти, професійна невизначеність» [7, с. 67].

Аналізуючи отримані дані в ході експериментальної роботи, ми дійшли висновку, що велика кількість соціальних працівників під час виконання професійних обов'язків перебуває в «зоні ризику» «професійного вигорання», саме тому пропонуємо низку методичних порад, реалізація яких у професійній сфері соціальних працівників якісно змінить рівень психоемоційного навантаження та дасть змогу мінімізувати симптоми.

Система профілактики «професійного вигорання» має включати діагностику психічних станів, консультативну роботу під керівництвом коуча, психолога чи самостійно, відвідування спеціалізованих тренінгів, метою яких $є$ емоційне врівноваження, розроблення індивідуальних планів щодо використання психологічних прийомів, завдяки яким психоемоційний стан працівника соціальної сфери буде врівноважено.

Ми поділяємо думку С. Мащак, що «профілактичні, лікувальні, реабілітаційні заходи вияву та подолання професійного вигорання особистості повинні сприяти обмеженню дії чинників стресу: зняття психічного напруження, під- вищення професійної мотивації, вирівнювання балансу між витраченими зусиллями, матеріальною, моральною винагородою, соціальним схваленням» [8, с. 450].

У свою чергу, пропонуємо в ході професійної діяльності намагатися включати елементи тим-білдингу, основною метою якого є згуртування колективу, проведення психологічних майстер-класів із розвитку професійної мобільності, 3 включенням здоров'язберігаючих принципів взаємодії з клієнтом, включення різного роду завдань 3 організації життєвого простору, тайм-менеджменту та швидкого перелаштування з одного виду діяльності на інший.

Важливе місце в питаннях підвищення стресостійкості посідає можливість правильного планування найближчих перспектив вирішення професійних завдань, саме тому, на нашу думку, варто формувати організацію себе та виконання професійних обов'язків.

Емоційний відпочинок не забаганка, а необхідний відпочинок мозку, саме тому пропонуємо керівництву соціальних служб організувати місце й час емоційного відновлення кожного соціального працівника.

Окрім вищезазначеного, уважаємо, що постійне підвищення рівня професійної кваліфікації, самоосвіта $\epsilon$ найкращими шляхами якісного виходу із симптомів «професійного вигорання».

Висновки й перспективи подальших розробок у цьому напрямі. Отже, на основі аналізу отриманої інформації ми дійшли висновку, що проблема «професійного вигорання» соціальних працівників - украй важлива, а вирішення основних завдань щодо подолання основних іiі симптомів має стати системним явищем у колективі працівників соціальної сфери, де класичні методи психологічної підтримки мають поєднуватися 3 арттерапевтичними та інноваційними технологіями підвищення рівня стресостійкості в системі роботи зі зменшення проявів емоційного виснаження, редукції та деперсоналізації. Подальші перспективи дослідження вбачаємо у вивченні впливу рівня розвитку професійної мобільності на подолання негативних тенденцій «професійного вигорання» працівників соціальної сфери.

\section{Література}

1. Freudenberger H.J. Staff burn-out. Journal of Social Issues, 1974. P. 159-166.

2. Maslach C., Schaufeli W., Leiter M. Job burnout Annu. Rev. Psychol. 2001. V. 52. P. 397-422.

3. Lloyd C., King R., Chenoweth L. Social work, stress and burnout: A review. Journal of Mental Health, 2002. V. 11. P. $255-256$.

4. Бойко В.В. Синдром эмоционального выгорания: диагностика и профилактика. Санкт-Петербург : Питер, 2008. 336 с

5. Водопьянова Н., Старченкова Е. Синдром выгорания: диагностика и профилактика. 2-е изд. Санкт-Петербург : Питер, 2009. 336 с. 
6. Жогно Ю.П. Психологічні особливості емоційного вигорання педагогів : автореф. дис. ... канд. психол. наук : 19.00.07 «Педагогічна та вікова психологія». Одеса, 2009. 22 с.

7. Керик О. Професійне вигорання та прояви «вторинної травми» у фахівців системи «людина-людина». Проблеми гуманітарних наук : збірник наукових праць ДДПУ імені Івана Франка. Дрогобич, 2013. Вип. 31 «Пихологія». С. 64-73.

8. Мащак С. Професійне вигорання особистості як соціально-психологічна проблема. Науковий вісник Львівського державного університету внутрішніх справ. Серія «Психологічна». 2012. Вип. 2 (1). C. $444-452$.

9. Перхайло Н. Попередження професійного вигоряння майбутніх працівників соціальної сфери. Педагогіка та психологія : збірник наукових праць. Харків, 2016. Вип. 55. С. 204-210.

10. Практическая психодиагностика. Методы и тесты / сост. Д. Рейгородский. Самара, 2000. 546 с.

11. Синдром «выгорания» в профессиях человек-человек. Практикум по психологии менеджмента и профессиональной деятельности. Санкт-Петербург, 2001, 386 с.

\section{References}

1. Freudenberger H.J. (1974) Staff burn-out. Journal of Social Issues. pp. 159-166.

2. Maslach C. Schaufeli W. Leiter M. (2001) Job burnout Annu. Rev. Psychol, vol. 52. pp. 397-422.

3. Lloyd C., King R., Chenoweth L. (2002) Social work, stress and burnout: A review. Journal of Mental Health, vol. 11. pp. 255-256.

4. Boyko V.V. (2008) Sindrom emotsionalnogo vyigoraniya: diagnostika i profilaktika SPB [Burnout syndrome: diagnosis and prevention]: Piter. $336 \mathrm{~s}$.

5. Vodopyanova H. Starchenkova E. (2009) Sindrom vyigoraniya: diagnostika i profilaktika. [Burnout syndrome: diagnosis and prevention] 2-e izd. SPb.: Piter, $336 \mathrm{~s}$.

6. Zhohno Yu. P. (2009) Psykholohichni osoblyvosti emotsiinoho vyhorannia pedahohiv: avtoref. dys. na zdobut. nauk. stupenia kand. psykhol. nauk: spets. 19.00.07 «Pedahohichna ta vikova psykholohiia» [Psychological features of the educational training of teachers] author's ref. dis. to obtain. science. degree of cand. psychol. science Odesa, $22 \mathrm{~s}$.

7. Keryk O. (2013) Profesiine vyhorannia ta proiavy «vtorynnoi travmy» u fakhivtsiv systemy «liudyna-liudyna» Problemy humanitarnykh nauk [Professionally vigorannya and show «secondary trauma» in specialist the «human-to-human» system]: Problems of the humanities: Coll. scientific works of the Ivan Franko State Pedagogical University. Vyp. 31. Psykholohiia Drohobych pp. 64-73.

8. Mashchak S. (2012) Profesiine vyhorannia osobystosti yak sotsialno-psykholohichna problema Naukovyi visnyk Lvivskoho derzhavnoho universytetu vnutrishnikh sprav. seriia psykholohichna. [Professional development of specialties as a social and psychological problem] Scientific Bulletin of Lviv State University of Internal Affairs psychological series. Vyp. 2 (1). s. 444-452.

9. Perkhailo H. (2016) Poperedzhennia profesiinoho vyhoriannia maibutnikh pratsivnykiv sotsialnoi sfery. Zbirnyk naukovykh prats «Pedahohika ta psykholohiia» [Advancement of the professional development of the future social workers]. Collection of scientific works «Pedagogy and Psychology» Kharkiv, Vyp. 55, s. $204-210$.

10. Reygorodskiy D. (ed.). (2000) [Prakticheskaya psihodiagnostika. Metodyi i testyiPractical psychodiagnostics. Methods and tests], Samara, $546 \mathrm{~s}$.

11. Sindrom «vyigoraniya» v professiyah chelovek-chelovek. Praktikum po psihologi menedzhmenta i professionalnoy deyatelnosti (2001) [The «burnout» syndrome in the human-human profession. Workshop on Management Psychologists and Professional Activities]. Spb, 386 s. 